\title{
Naphthoquinone-thiazole hybrids bearing adamantane: Synthesis, antimicrobial, DNA cleavage, antioxidant activity, acid dissociation constant, and drug-likeness
}

\author{
Ayşegül DOĞAN 1 (D), Sadin ÖZDEMİR ${ }^{2}$ D , Mustafa Serkan YALÇIN ${ }^{3}$ D, Hayati SARI 4 (D), \\ Yahya NURAL 5, 6* \\ 1 Department of Analytical Chemistry, Faculty of Pharmacy, Hacettepe University, 06100 Ankara, Turkey \\ 2 Food Processing Programme, Technical Science Vocational School, Mersin University, 33343 Mersin, Turkey \\ 3 Department of Chemistry and Chemical Processing Technologies, Technical Science Vocational School, Mersin \\ University, TR-33343 Mersin, Turkey \\ 4 Department of Chemistry, Faculty of Science and Arts, Tokat Gaziosmanpasa University, 60250 Tokat, Turkey \\ 5 Department of Analytical Chemistry, Faculty of Pharmacy, Mersin University, 33169 Mersin, Turkey \\ 6 Advanced Technology, Research and Application Center, Mersin University, 33343 Mersin, Turkey \\ * Corresponding Author. E-mail: ynural1805@yahoo.com; yahyanural@mersin.edu.tr (Y.N.); Tel. +90-324-341 28 15.
}

Received: 01 November 2020 / Revised: 28 February 2021 / Accepted: 26 March 2021

\begin{abstract}
In this study, four novel naphthoquinone-thiazole hybrids bearing adamantane were synthesized by reaction of naphthoquinone-aroylthiourea derivatives with 1-adamantyl bromomethyl ketone in 75-85\% yield and were characterized using ${ }^{1} \mathrm{H} /{ }^{13} \mathrm{C}$ NMR, FT-IR, and HRMS techniques. Various biological activities of the synthesized compounds, such as antibacterial, antifungal, DNA cleavage, and antioxidant activities, were screened. The compounds showed antibacterial activity against Escherichia coli, Bacillus cereus, Staphylococcus aureus, Pseudomonas aeruginosa, Enterococcus hirae, and Legionella pneumophila subsp. pneumophila strains with MIC values in the range of 4-64 $\mu \mathrm{g} / \mathrm{mL}$ and antifungal activity against Candida albicans strains with MIC values in the range of $16-64 \mu \mathrm{g} / \mathrm{mL}$. The compounds had DNA cleavage activity at 250 and $500 \mu \mathrm{g} / \mathrm{mL}$. Additionally, the antioxidant activity of the compounds was assessed based on the radical scavenging effect of the stable DPPH (2,2-diphenyl-1-picrylhydrazyl) free radical and the compounds exhibited acceptable antioxidant activity. The acid dissociation constants $\left(\mathrm{p} K_{\mathrm{a}}\right)$ of the compounds were determined potentiometrically in $30 \%(\mathrm{v} / \mathrm{v})$ dimethyl sulfoxide-water at an ionic background of $0.1 \mathrm{~mol} \mathrm{~L}^{-1} \mathrm{NaCl}$, at 25 $\pm 0.1^{\circ} \mathrm{C}$, and the HYPERQUAD computer program was used to calculate the $\mathrm{p} K_{\mathrm{a}}$ values from the data obtained from potentiometric titrations. Prediction of the drug-likeness properties of the compounds was performed with the use of the MolSoft website, and the compounds had promising drug-likeness model scores within a range of 1.09-1.56.
\end{abstract}

KEYWORDS: Naphthoquinone; thiazole; adamantane; antimicrobial; antioxidant; DNA cleavage; acid dissociation constant; drug-likeness.

\section{INTRODUCTION}

Many compounds containing naphthoquinone scaffolds occur naturally and play an active role in biological processes of various fungi, bacteria, and plants [1]. Naphthoquinones are considered to be an important pharmacophore in pharmaceutical chemistry because many biologically active compounds, such as atovaquone, doxorubicin, buparvaquone, and lapachol, contain a naphthoquinone scaffold in their molecular structures (Figure 1) [2-4]. It is known that synthetic or natural products of 1,4-naphthoquinone derivatives exhibit a wide range of biological activities, such as antibacterial, antifungal [5-7], antimalarial [8], antioxidant [9, 10], and anticancer [11-13], as well as tyrosinase [14] and trypanothione reductase inhibition [15]. Moreover, naphthoquinones have been considered as active components of many herbs used in traditional medicine, such as Lithospermum erythrorhizon and Onosma hookeri Clarke var. longiforum Duthie [16].

The thiazole scaffold is one of the pharmacophores attracting the most interest recently and numerous bioactive compounds, such as tiazofurin, ravuconazole, dasatinib, and dabrafenib, contain a thiazole core (Figure 2) [17-20]. Additionally, a great number of thiazole hybrids exhibit a broad spectrum of biological activity, including antibacterial, antifungal [21-23], antimycobacterial [22-24], antiviral [25], and anticancer [2628] activities, as well as lanosterol 14-a demethylase [29] and xanthine oxidase [30] inhibition.

How to cite this article: Doğan A, Özdemir S, Yalçın MS, Sarı H, Nural Y. Naphthoquinone-thiazole hybrids bearing adamantane: synthesis, antimicrobial, DNA cleavage, antioxidant activity, acid dissociation constant, and drug-likeness. J Res Pharm. 2021; 25(3): 292-304. 

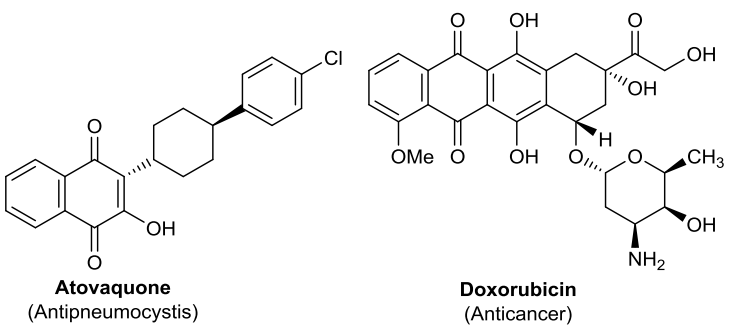

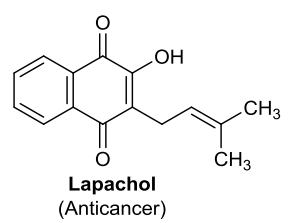

Figure 1. Some pharmaceuticals containing naphthoquinone core.

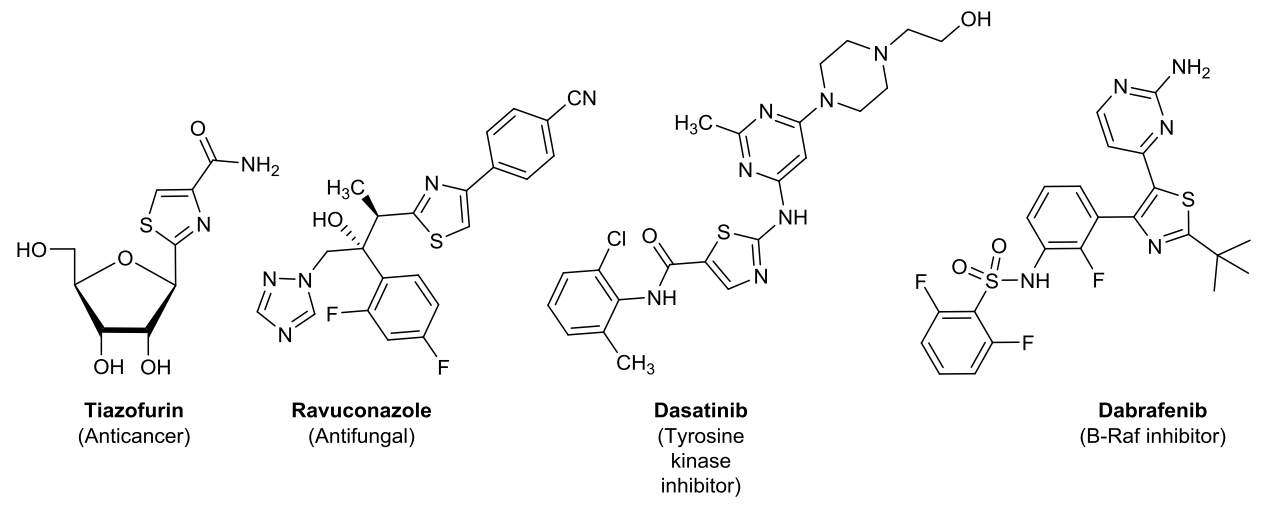

Figure 2. Some pharmaceuticals containing thiazole core.

Whether isolated from plants as natural products or produced synthetically, many derivatives of adamantane, which is a highly symmetric polycyclic cage molecule, show various pharmacological properties [31]. Adamantane is now commonly included in biologically active compounds to increase their lipophilicity and improve their pharmacological properties [32].

The $\mathrm{p} K_{\mathrm{a}}$ value is a critical parameter of a substance because it gives information about acidity/basicity, hydrogen-bonding capacity, and solubility, which are useful for understanding the nature of compounds. Knowing the $\mathrm{p} K_{\mathrm{a}}$ value(s) of a biologically active compound is essential in drug research because $\mathrm{p} K_{\mathrm{a}}$ values determine the solubility, absorption, distribution, metabolism, and elimination of molecules. Furthermore, the $\mathrm{pK}_{\mathrm{a}}$ value is also a useful parameter to optimize separation procedures [33-37]. Potentiometric and spectrophotometric titration methods are the oldest and most widely used methods to determine $\mathrm{p} K_{\mathrm{a}}$ values $[38,39]$.

In this study, the synthesis and investigation of the broad biological activities of four compounds including naphthoquinone, thiazole, and adamantane moieties are reported. Additionally, determination of the $\mathrm{p} K_{\mathrm{a}}$ values and calculation of the drug-likeness properties of the products have also been performed.

\section{RESULTS AND DISCUSSION}

Naphthoquinone-thiazole hybrids bearing adamantane (6a-d) were synthesized by reaction of $1,4-$ naphthoquinone $\mathrm{N}$-aroylthioureas $\mathbf{4 a - d}$ and 1-adamantyl bromomethyl ketone $\mathbf{5}$ under reflux temperature with $75-85 \%$ yield (Figure 5). The 1,4-naphthoquinone $N$-aroylthioureas $\mathbf{4 a - d}$ were prepared in three steps using 2,3-dichloronaphthalene-1,4-dione $\mathbf{1}$ as the starting compound [40]. Molecular structures of $\mathbf{6 a - d}$ were characterized using FT-IR, ${ }^{1} \mathrm{H}$ NMR, ${ }^{13} \mathrm{C}$ NMR and HRMS techniques. In the FT-IR spectra of $\mathbf{6 a}-\mathbf{d}$, strong aliphatic C-H stretching peaks were observed in the range of $2960-2846 \mathrm{~cm}^{-1}$. Additionally, the bands observed in the range of $1652-1650 \mathrm{~cm}^{-1}$ were attributed to the $\mathrm{C}=\mathrm{O}$ groups. In the ${ }^{1} \mathrm{H}$ NMR spectra of $6 \mathrm{a}-\mathrm{d}$, the singlet peak observed in the range of $6.79-6.68 \mathrm{ppm}$ was attributed to the proton of the thiazole ring. Moreover, multiple peaks in the ranges of 1.91-1.79 ppm and 1.64-1.51 ppm whose integrals corresponded to 9 protons and 6 protons, respectively, indicated that the adamantane moiety was present in the molecular structure of the products. In the ${ }^{13} \mathrm{C}$ NMR spectra of $\mathbf{6 a}-\mathbf{d}$, peaks related to the $\mathrm{C}=\mathrm{O}$ groups were observed in the range of $181.3-171.3 \mathrm{ppm}$. The peak observed in the range of 171.1-170.6 ppm was attributed to the carbon of the $\mathrm{C}=\mathrm{N}$ group formed after cyclization. There are four types of carbon atoms with different chemical environments in the adamantane moiety, and their associated peaks were observed at approximately $40.2 \mathrm{ppm}, 36.0 \mathrm{ppm}, 35.6$ ppm, and $27.7 \mathrm{ppm}$. 


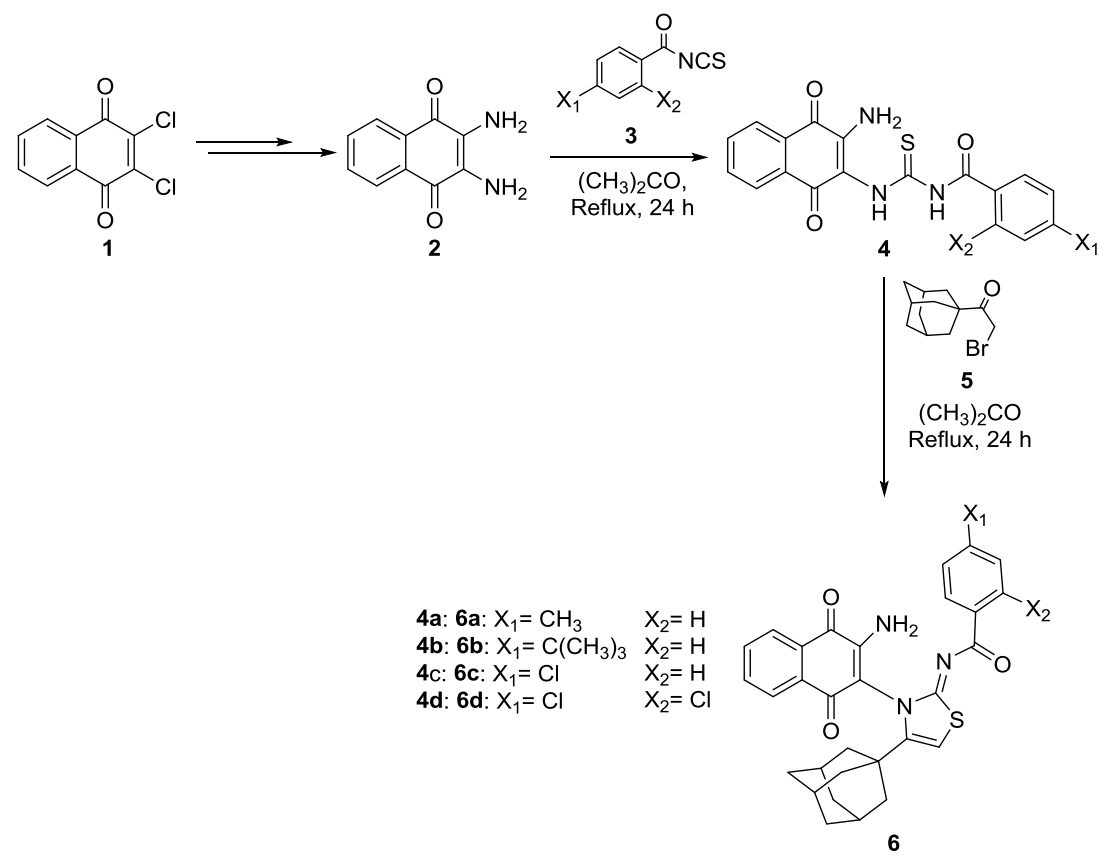

Figure 3. Synthesis of the naphthoquinone-thiazole hybrids bearing adamantane (6a-d).

Antibacterial activity studies of $\mathbf{6 a}-\mathbf{d}$ molecules were performed against six bacterial strains. The twofold serial broth dilution process was applied. The naphthoquinone-thiazole hybrids bearing adamantane (6ad) inhibited the growth of bacteria at minimum inhibitory concentrations (MICs) of 4 to $64 \mu \mathrm{g} / \mathrm{mL}$ and the reference drug ampicillin exhibited antibacterial activity with MIC values in the range of $0.5-1 \mu \mathrm{g} / \mathrm{mL}$ against the same bacteria strains (Table 1). Compound 6a, containing the methyl group as a substituent at the para position of the phenyl ring, showed antibacterial activity against $E$. coli strains with a MIC value of $16 \mu \mathrm{g} / \mathrm{mL}$. For the same bacterial strain, $\mathbf{6 b}$ containing tert-butyl as $X_{1}, \mathbf{6 c}$ containing a chlorine atom as $X_{1}$, and $\mathbf{6 d}$ containing chlorine atoms as $\mathrm{X}_{1}$ and $\mathrm{X}_{2}$ exhibited antibacterial activity with MIC values of 32, 32, and 64 $\mu \mathrm{g} / \mathrm{mL}$, respectively. Compound 6a showed antibacterial activity against B. cereus and P. aeruginosa strains with a MIC value of $8 \mu \mathrm{g} / \mathrm{mL}$, and replacement of the methyl group with other substituents (tert-butyl or chlorine atom) in compounds $\mathbf{6 b}-\mathbf{d}$ caused a decrease in antibacterial activity against $B$. cereus and $P$. aeruginosa. Although 6a and $\mathbf{6 c}$ showed antibacterial activity with a MIC value of $8 \mu \mathrm{g} / \mathrm{mL}$ against $S$. aureus, the best antibacterial activity against $S$. aureus was obtained by compound $6 \mathbf{b}$ with a MIC value of $4 \mu \mathrm{g} / \mathrm{mL}$. Compound $\mathbf{6 b}$ also showed antibacterial activity against $E$. hirae with a MIC value of $8 \mu \mathrm{g} / \mathrm{mL}$, while compounds $\mathbf{6 a}$ and $\mathbf{6 c}$ showed antibacterial activity with a MIC value of $4 \mu \mathrm{g} / \mathrm{mL}$ against the same strain. Compound $\mathbf{6 c}$ showed the best antibacterial activity against L. pneumophila subsp. pneumophila with a MIC value of $4 \mu \mathrm{g} / \mathrm{mL}$, while compounds $\mathbf{6 a}, \mathbf{6 b}$, and $\mathbf{6 d}$ showed antibacterial activity with MIC values of 16, 64, and $32 \mu \mathrm{g} / \mathrm{mL}$, respectively, against the same bacterial strain. Thus, these naphthoquinone-thiazole hybrids bearing adamantane (6a-d) possessed a broad spectrum of antibacterial activity. It can be said that compounds 6a-d showed better antibacterial activity against the S. aureus and E. hirae strains than the other bacterial strains and compounds $\mathbf{6 a - d}$ can be considered as good starting points for further development of antibacterial agents.

Antifungal activity study of $\mathbf{6 a - d}$ was performed against $C$. albicans and it was found that these compounds exhibited antifungal activity with MIC values in the range of $16-64 \mu \mathrm{g} / \mathrm{mL}$. Meanwhile, the reference drug fluconazole exhibited antifungal activity with a MIC value of $0.5 \mu \mathrm{g} / \mathrm{mL}$ against C. albicans. Consequently, it can be said that compounds $\mathbf{6 a}-\mathbf{d}$ showed moderate antifungal activity against $\mathbf{C}$. albicans.

The chemical nuclease activities of $\mathbf{6 a}-\mathbf{d}$ were screened using the agarose gel electrophoresis method. This method was applied using two different concentrations ( 250 and $500 \mu \mathrm{g} / \mathrm{mL}$ ) of compounds $6 \mathbf{a}-\mathbf{d}$. Plasmid DNA and DMSO-treated plasmid DNA were used as controls. After gel electrophoresis, as can be clearly seen in Figure 4, all compounds had nuclease activity and showed double-strained plasmid DNA cleaving ability (lanes 1-8), whereas control studies showed that untreated DNA and DNA treated with DMSO alone did not demonstrate any significant DNA cleavage (lanes 9, 10). Based on the results of this study, it can be said that $\mathbf{6 a}-\mathbf{d}$ may have promising effects in several types of medical treatment and also in cancer therapy after further clinical studies. 


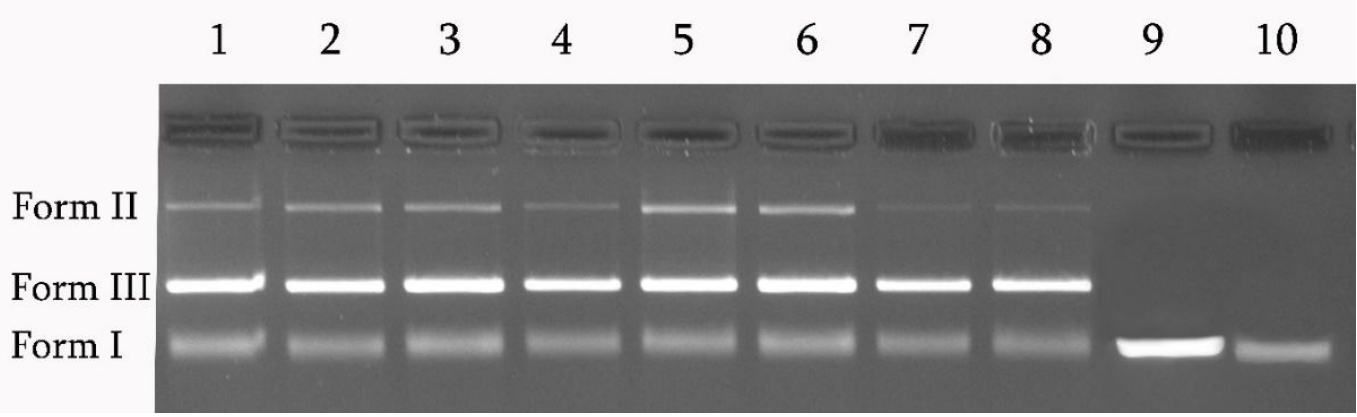

Lane 1, pBR $322 \mathrm{DNA}+250 \mu \mathrm{g} / \mathrm{mL}$ of $\mathbf{6 a}$; Lane 2, pBR $322 \mathrm{DNA}+250 \mu \mathrm{g} / \mathrm{mL}$ of $\mathbf{6 b}$; Lane 3, pBR $322 \mathrm{DNA}+250 \mu \mathrm{g} / \mathrm{mL}$ of 6c; Lane 4, pBR $322 \mathrm{DNA}+250 \mu \mathrm{g} / \mathrm{mL}$ of $\mathbf{6 d}$; Lane $5 \mathrm{pBR} 322 \mathrm{DNA}+500 \mu \mathrm{g} / \mathrm{mL}$ of $\mathbf{6 a}$; Lane 6, pBR $322 \mathrm{DNA}+500$ $\mu \mathrm{g} / \mathrm{mL}$ of $\mathbf{6 b}$; Lane 7, pBR 322 DNA $+500 \mu \mathrm{g} / \mathrm{mL}$ of $\mathbf{6 c}$; Lane 8, pBR $322 \mathrm{DNA}+500 \mu \mathrm{g} / \mathrm{mL}$ of $\mathbf{6 d}$; Lane 9, pBR 322 DNA; Lane 10, pBR 322 DNA + DMSO

Figure 4. DNA cleavage activities of test compounds.

Table 1. The MIC values $(\mu \mathrm{g} / \mathrm{mL})$ of $\mathbf{6 a}-\mathbf{d}$ against bacterial and fungal strains.

\begin{tabular}{cccccccc}
\hline \multirow{2}{*}{ Compounds/Standards } & \multicolumn{7}{c}{ Microorganisms* $^{*}$} \\
\cline { 2 - 9 } & EC & BC & SA & PA & EH & LPP & CA \\
\hline 6a & 16 & 8 & 8 & 8 & 4 & 16 & 16 \\
6b & 32 & 32 & 4 & 32 & 8 & 64 & 64 \\
6c & 32 & 64 & 8 & 64 & 4 & 4 & 32 \\
6d & 64 & 64 & 32 & 64 & 64 & 32 & 32 \\
Fluconazole & - & - & - & - & - & - & 0.5 \\
Ampicillin & 0.5 & 1 & 1 & 0.5 & 0.5 & 0.5 & -
\end{tabular}

* EC: Escherichia coli (ATCC 10536); BC: Bacillus cereus; SA: Staphylococcus aureus (ATCC 6538); PA: Pseudomonas aeruginosa (ATCC 9027); EH: Enterococcus hirae (ATCC 10541); LPP: Legionella pneumophila subsp. pneumophila (ATCC 33152); CA: Candida albicans.

The antioxidant activity of the naphthoquinone-thiazole hybrids bearing adamantane (6a-d) was evaluated against DPPH radical. The impact of antioxidant agents on DPPH is thought to be due to their hydrogen-donating activity. Free radical scavenging abilities are very significant to prevent the harmful actions of radicals in various diseases, such as cancer. As can be seen in Figure 5(a), the radical scavenging effect of compounds $\mathbf{6 a - d}$ increased with increasing concentrations. Compounds 6a-d exhibited DPPH scavenging ability of $30.5 \%, 26.6 \%, 21.8 \%$, and $15.8 \%$ in the order of $\mathbf{6 a}>\mathbf{6 c}>\mathbf{6} \mathbf{d}>\mathbf{6 b}$, respectively, at a concentration of $250 \mathrm{mg} / \mathrm{L}$. When the concentrations of $6 \mathbf{a}-\mathbf{d}$ increased from $250 \mathrm{mg} / \mathrm{L}$ to $500 \mathrm{mg} / \mathrm{L}$, the scavenging activities increased from $54.6 \%$ to $66.3 \%$, from $39.2 \%$ to $46.6 \%$, from $57.7 \%$ to $62.4 \%$, and from $41.7 \%$ to $46.2 \%$, respectively. Acceptable effects were recorded at the $500 \mathrm{mg} / \mathrm{L}$ concentration for compounds 6a and $6 \mathrm{c}$ as $66.3 \%$ and $62.4 \%$, respectively. Ascorbic acid and Trolox, used as reference compounds, had a $100 \%$ radical scavenging effect at the same concentrations. Finally, it can be said that for $\mathbf{6 a}$ and $\mathbf{6 c}$, modification of the substituents $\left(\mathrm{X}_{1}=-\mathrm{CH}_{3}\right.$ and $\left.-\mathrm{Cl}\right)$ in the structure of the naphthoquinone-thiazole hybrids bearing adamantane caused a significant change in free radical scavenging activity.

The emergence of most reactive oxygen species is due to the electron transport system and other metabolic activities, and reactive oxygen species are produced by metal-catalysed oxidation reactions [41]. Ferrozine forms a complex with ferrous ions and a magenta colour appears. In the presence of any chelating agents, the formation of the iron-ferrozine complex is inhibited, and, as a result, the magenta colour's intensity is reduced. The metal chelating abilities of $\mathbf{6 a}-\mathbf{d}$ were determined by applying the ferrozine test. The results are presented in Figure 5(b). The reducing abilities on $\mathrm{Fe}^{2+}$ were in the following order at $100 \mathrm{mg} / \mathrm{L}$ : $\mathbf{6 b}>\mathbf{6 a}>\mathbf{6 c}>\mathbf{6 d}$. The ferrous chelating activities were also determined at $250 \mathrm{mg} / \mathrm{L}$ and $\mathbf{6 a}, \mathbf{6 b}, \mathbf{6 c}$, and $\mathbf{6 d}$ showed respective activities of $38.4 \%, 45.3 \%, 27.4 \%$, and $20.9 \%$, respectively. The highest $\mathrm{Fe}^{2+}$ reducing ability was obtained as $57.9 \%$ with compound $\mathbf{6 b}$. The evaluation of the antioxidant activity revealed that tested compounds $\mathbf{6 a}$ and $\mathbf{6 b}$ exhibited acceptable metal chelating ability compared with the positive control, EDTA. The variability of the metal chelating ability can be attributed to modifications of the substituents in the structure of the naphthoquinone-thiazole hybrids bearing adamantane. 


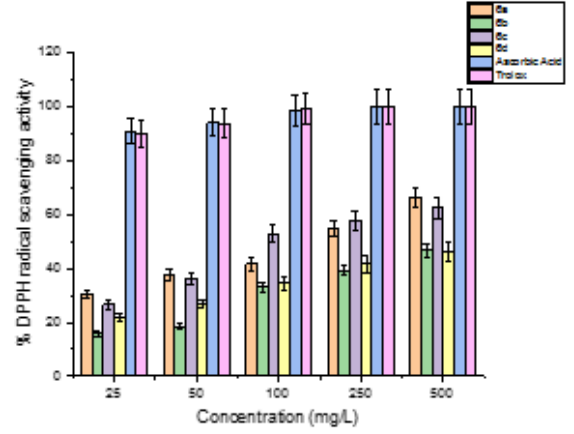

(a)

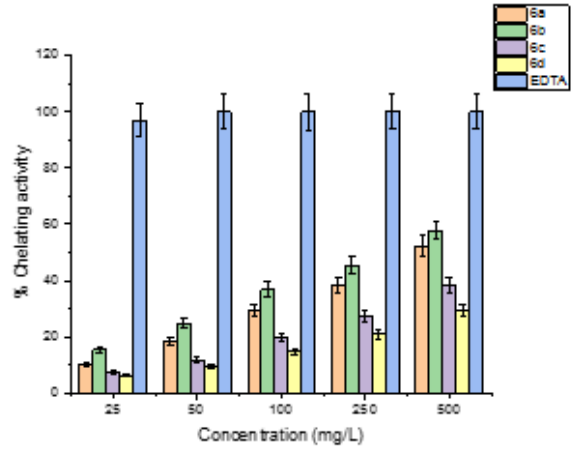

(b)

Figure 5. \% Radical scavenging (a) and chelating (b) activity of 6a-d.

The $\mathrm{p} K_{\mathrm{a}}$ values of compounds $6 \mathbf{a}-\mathbf{d}$ were determined in a DMSO-water mixture because they have low solubility in water. DMSO-water mixtures have various advantages, such as compatibility with the standard glass electrode and a large acidity range, and are therefore among the most widely used solvent systems for potentiometric determination of $\mathrm{p} K_{\mathrm{a}}$ values [42, 43]. The $\mathrm{p} K_{\mathrm{a}}$ values of $\mathbf{6 a}-\mathbf{d}$ were determined potentiometrically in an acidic medium at $25.0 \pm 0.1{ }^{\circ} \mathrm{C}$ and $0.1 \mathrm{M} \mathrm{NaCl}$ ionic strength in $30 \%(\mathrm{v} / \mathrm{v})$ DMSOwater hydro-organic solvent. As shown in Figure 7, we expect such compounds to be protonated by seven different groups. In this study, we determined four $\mathrm{p} K_{\mathrm{a}}$ values each for $\mathbf{6} \mathbf{a}$ and $\mathbf{6} \mathbf{d}$ and three $\mathrm{p} K_{\mathrm{a}}$ values each for $\mathbf{6 b}$ and $\mathbf{6} \mathbf{c}$ using the HYPERQUAD computer program to calculate the $\mathrm{p} K_{\mathrm{a}}$ values from the data obtained from potentiometric titrations. Potentiometric titration and distribution curves of $\mathbf{6 a} \mathbf{a} \mathbf{d}$ obtained from potentiometric titrations are given in Figure 6.
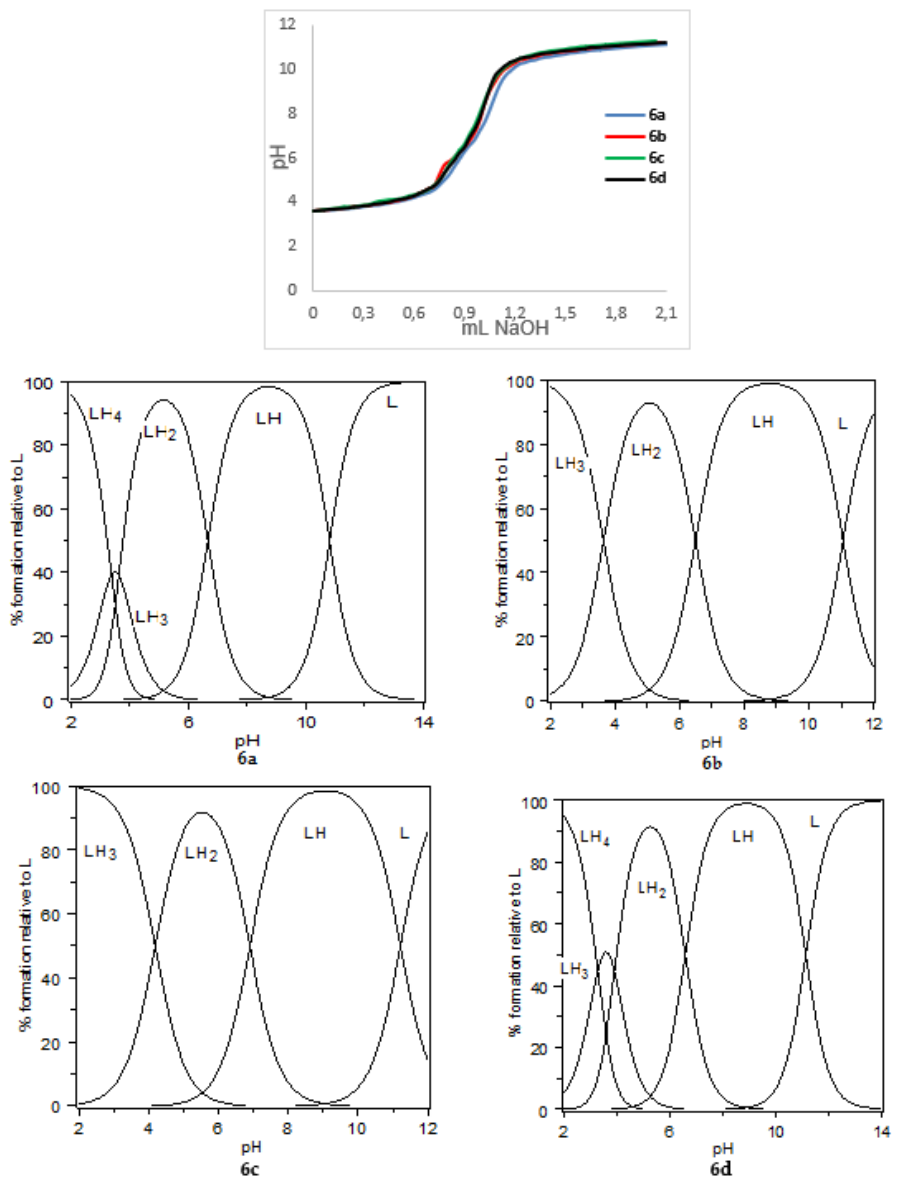

Figure 6. Potentiometric titration and distribution curves of $\mathbf{6 a - d}$ in acidic medium (25.0 \pm 0.1 ${ }^{\circ} \mathrm{C}, 0.1 \mathrm{M} \mathrm{NaCl}$ in $30 \%$ (v/v) DMSO-water). 

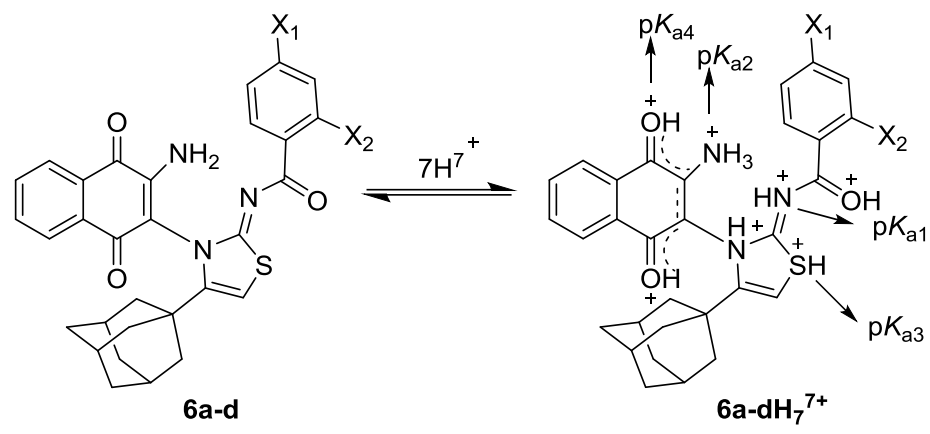

Figure 7. Full protonated form of the ligands $6 \mathrm{a}-\mathrm{dH}_{7}{ }^{7+}$.

There are three nitrogen atoms in the molecular structure of compounds $\mathbf{6 a}-\mathbf{d}$ and all of the nitrogen atoms have conjugation. Altun et al. [44] reported that the $\mathrm{p} K_{\mathrm{a}}$ values of the imine nitrogen atom, the nitrogen atom on the thiazole ring, and the phenolate oxygen atom were obtained in the ranges of 2.46-2.85, 2.86-4.92, and 8.89-11.61, respectively, in a 60\% dioxane-water mixture. Gemili et al. [40] reported that the $\mathrm{p} K_{\mathrm{a}}$ values of the amine nitrogen atom bound to the 1,4-naphthoquinone ring $-\mathrm{SH}$ and $-\mathrm{OH}$ groups that formed after protonation of the thiocarbonyl group and carbonyl group on the 1,4-naphthoquinone ring in acidic medium were obtained in the ranges of 4.79-5.64, 6.21-6.48, and 8.95-9.54, respectively, in a 50\% DMSO-water mixture.

The $\mathrm{p} K_{\mathrm{a} 1}, \mathrm{p} K_{\mathrm{a} 2}, \mathrm{p} K_{\mathrm{a} 3}$, and $\mathrm{p} K_{\mathrm{a} 4}$ values of $\mathbf{6 a}$ and $\mathbf{6} \mathbf{d}$ were found as $3.37 \pm 0.10$ and $3.26 \pm 0.11,3.63 \pm 0.12$ and $3.90 \pm 0.11,6.67 \pm 0.07$ and $6.58 \pm 0.08$, and $10.82 \pm 0.04$ and $11.13 \pm 0.04$, respectively (Table 2). We propose that the $\mathrm{p} K_{\mathrm{a} 1}, \mathrm{p} K_{\mathrm{a} 2}, \mathrm{p} K_{\mathrm{a} 3}$, and $\mathrm{p} K_{\mathrm{a} 4}$ values are related to the imine nitrogen atom $\left(\mathrm{C}=\mathrm{NH}^{+}\right)$, the amine nitrogen atom bound to the 1,4-naphthoquinone ring $\left(\mathrm{NH}_{3}{ }^{+}\right)$, the sulphur atom on the thiazole ring, and one of the oxygen atoms of the carbonyl groups on the 1,4-naphthoquinone ring, respectively. However, the $\mathrm{p} K_{\mathrm{a}}$ values of the other three protonated species could not be determined. The $\mathrm{p} K_{\mathrm{a} 1}, \mathrm{p} K_{\mathrm{a} 2}$, and $\mathrm{p} K_{\mathrm{a} 3}$ values of $\mathbf{6} \mathbf{b}$ and $\mathbf{6 c}$ were found as $3.65 \pm 0.13$ and $4.18 \pm 0.13,6.49 \pm 0.09$ and $6.90 \pm 0.11$, and $11.06 \pm 0.07$ and $11.22 \pm 0.05$, respectively (Table 2). We suggest that the $\mathrm{p} K_{\mathrm{a} 1}, \mathrm{p} K_{\mathrm{a} 2}$, and $\mathrm{p} K_{\mathrm{a} 3}$ values are related to the amine nitrogen atom bound to the 1,4-naphthoquinone ring $\left(\mathrm{NH}_{3}{ }^{+}\right)$, the sulphur atom on the thiazole ring, and one of the oxygen atoms of the carbonyl groups on the 1,4-naphthoquinone ring, respectively. In addition to the three protonated species that were in the molecular structures of $\mathbf{6 a}$ and $\mathbf{6} \mathbf{d}$ and whose $\mathrm{p} K_{\mathrm{a}}$ values could not be determined, the $\mathrm{p} K_{\mathrm{a}}$ values related to the imine nitrogen atom $\left(\mathrm{C}=\mathrm{NH}^{+}\right)$for $\mathbf{6} \mathbf{b}$ and $\mathbf{6 c}$ could not be determined.

Table 2. The $\mathrm{p} K_{\mathrm{a}}$ values of $\mathbf{6 a}-\mathbf{d}$ in acidic medium $\left(25.0 \pm 0.1{ }^{\circ} \mathrm{C}, 0.1 \mathrm{M} \mathrm{NaCl}\right.$ in $30 \%(\mathrm{v} / \mathrm{v})$ DMSO-water).

\begin{tabular}{lllll}
\hline Compound & $\mathrm{p} \boldsymbol{K}_{\mathrm{a} 1}$ & $\mathrm{p} \boldsymbol{K}_{\mathrm{a} 2}$ & $\mathrm{p} \boldsymbol{K}_{\mathrm{a} 3}$ & $\mathrm{p} \boldsymbol{K}_{\mathrm{a} 4}$ \\
\hline $\mathbf{6 a}$ & $3.37 \pm 0.10$ & $3.63 \pm 0.12$ & $6.67 \pm 0.07$ & $10.82 \pm 0.04$ \\
$\mathbf{6 b}$ & $3.65 \pm 0.13$ & $6.49 \pm 0.09$ & $11.06 \pm 0.07$ & \\
$\mathbf{6 c}$ & $4.18 \pm 0.13$ & $6.90 \pm 0.11$ & $11.22 \pm 0.05$ & \\
$\mathbf{6 d}$ & $3.26 \pm 0.11$ & $3.90 \pm 0.11$ & $6.58 \pm 0.08$ & $11.13 \pm 0.04$ \\
\hline
\end{tabular}

Many drug candidates are eliminated in the further stages of drug research because of their weak pharmacokinetic properties. Determination of pharmacokinetic properties of compounds in the first step avoids the loss of time and money. The "drug-likeness" concept was proposed to eliminate molecules that do not have suitable properties at the initial stage to minimize losses in later stages of drug research. $p K_{a}$ values, lipophilicity, number of hydrogen bond donors and recipients, polar surface area, and percentage absorption are useful parameters that help determine the pharmacokinetic properties of drug candidate molecules. There are many statistical programs developed to estimate the drug-likeness properties of compounds $[45,46]$.

In this study, to estimate the pharmacokinetic and drug-likeness properties of compounds $6 \mathbf{a}-\mathbf{d}$, a theoretical study was performed using the MolSoft website. The MolSoft programme uses many estimated parameters such as number of hydrogen bond donors (HBDs) and acceptors (HBAs), topological polar surface area (TPSA), molecular volume, etc. and calculates a drug-likeness model score (DLS), which is a parameter that predicts the extent to which a compound will possess the properties of drug molecules [47]. Some of the parameters obtained are summarized in Table 3 . The percentage of absorption (\% ABS) was calculated using the formula $\% \mathrm{ABS}=109-(0.345 \times \mathrm{TPSA})$ as given in the literature [48] 
Table 3. Drug-likeness calculations of compounds 6a-d.

\begin{tabular}{ccccccc}
\hline Comp. & HBA $^{\mathrm{a}}$ & $\mathrm{HBD}^{\mathrm{b}}$ & $\begin{array}{c}\mathrm{TPSA}^{\mathrm{c}} \\
\left(\mathrm{A}^{2}\right)\end{array}$ & $\begin{array}{c}\text { Volume } \\
\left(\mathrm{A}^{3}\right)\end{array}$ & $\begin{array}{c}\text { \%ABSe }=109- \\
(0.345 \times \text { TPSA })\end{array}$ & DLS \\
\hline 6a & 5 & 2 & 72.14 & 556.83 & 84.11 & 1.19 \\
6b & 5 & 2 & 72.14 & 620.50 & 84.11 & 1.09 \\
6c & 5 & 2 & 72.14 & 553.08 & 84.11 & 1.56 \\
6d & 5 & 2 & 72.14 & 568.48 & 84.11 & 1.14 \\
\hline
\end{tabular}

Molecular volume, e = Percentage absorption

The numbers of HBDs and HBAs for each compound were found to be 2 and 5, respectively. DLS values ranged in the order of $\mathbf{6 b}<\mathbf{6 d}<\mathbf{6 a}<\mathbf{6 c}$, which means that $\mathbf{6 c}$ has the best pharmacokinetic properties according to MolSoft calculations. $\mathbf{6 c}$, containing a chlorine atom in the para position of the phenyl ring as a substituent, had the maximum DLS value of 1.56 (Figure 8). Binding the chlorine atom to both the ortho position and the para position of the phenyl ring causes a decrease in the DLS value. As a result, although $6 \mathrm{c}$ has the highest DLS, considering Figure 6, the DLS values of 6a-d show that all of the compounds have good pharmacokinetic properties with DLS values in the range of 1.09-1.56.

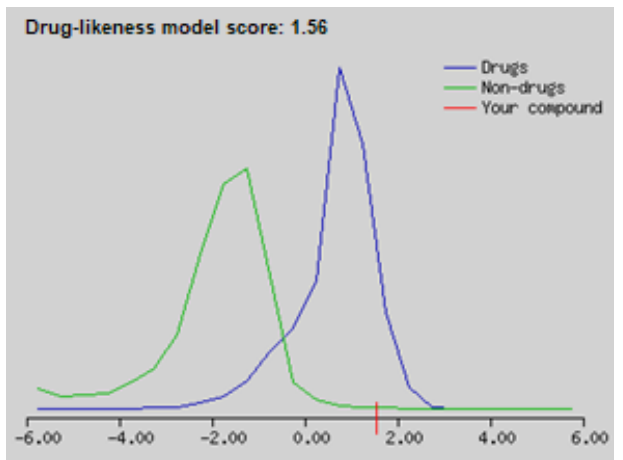

Figure 8. Calculated drug-likeness model score for $\mathbf{6 c}$ using the MolSoft website.

\section{CONCLUSION}

In summary, we have demonstrated the synthesis of naphthoquinone-thiazole hybrids bearing adamantane by the reaction of 1,4-naphthoquinone $\mathrm{N}$-aroylthiourea derivatives and 1-adamantyl bromomethyl ketone. These compounds have three very important pharmacophore groups that are desired to be found in the molecular structure of the compounds in pharmaceutical studies are reported. The compounds exhibited antibacterial activity with MIC values in the range of 4-64 $\mu \mathrm{g} / \mathrm{mL}$ and their antibacterial activities are promising for future studies. Furthermore, the compounds exhibited moderate antifungal activity with MIC values in the range of $16-64 \mu \mathrm{g} / \mathrm{mL}$. All of the compounds showed DNA cleavage activity and these results indicate that the compounds can be considered as good starting points for further anticancer studies. The compounds showed moderate antioxidant and ferrous chelating activities. The $\mathrm{p} K_{\mathrm{a}}$ values, which are critical for the further study of the compounds, were determined potentiometrically using the HYPERQUAD computer program in 30\% (v/v) DMSO-water hydro-organic solvent. Furthermore, all of the compounds had valuable drug-likeness model scores within a range of 1.09-1.56, and these results indicate that these naphthoquinone-thiazole hybrids bearing adamantane have good pharmacokinetic properties for further studies.

\section{MATERIALS AND METHODS}

\subsection{Synthesis}

High-purity precursor chemicals were purchased from Merck or Aldrich. A PerkinElmer spectrophotometer for Fourier-transform infrared spectroscopy (FTIR) spectra and a Bruker Ultrashield Plus Biospin at $400 \mathrm{MHz}$ for nuclear magnetic resonance (NMR) spectra and decoupling experiments were utilized. Chemical shifts are given in parts per million $(\delta)$ downfield from TMS (tetramethylsilane, internal standard). Dimethyl sulfoxide- $d_{6}$ was used in obtaining spectra. Abbreviations used are as follows: s: singlet, d: doublet, dd: doublet of doublets, td: triplet of doublets, m: multiplet. An Agilent 6224 TOF LC-ESI-MS was used for 
recording high-resolution mass spectra (HRMS). A Mettler Toledo MP90 device was used for determination of melting points. A Titroline 7000 automated titrator with SI-Analytics combined with a glass electrode, which could be controlled by a computer and had an automatic micro-burette, was used for $\mathrm{pH}$-metric titrations.

\subsubsection{Synthesis of 1,4-naphthoquinone $N$-aroylthioureas $(4 a-d)$}

The 1,4-naphthoquinone $N$-aroylthioureas $4 \mathbf{a}$-d were prepared as established in our previous study [40] by reacting 2,3-diaminonaphthalene-1,4-dione (2), which was prepared from 2,3-dichloronaphthalene-1,4dione 1 and the corresponding aroylisothiocyanates 3 . A solution of the corresponding aroyl chloride ( $2 \mathrm{mmol})$ in acetone $(20 \mathrm{~mL})$ was added to a stirred solution of potassium thiocyanate $(2 \mathrm{mmol})$ in acetone $(20 \mathrm{~mL})$, and then the reaction mixture was stirred at reflux temperature for $2 \mathrm{~h}$. After $2 \mathrm{~h}$, a solution of 2,3diaminonaphthalene-1,4-dione $(1 \mathrm{mmol})$ in acetone $(10 \mathrm{~mL})$ was added dropwise to the reaction medium and heated at reflux temperature for a further $22 \mathrm{~h}$. When the reaction was determined to be complete, the solvent was evaporated using a rotary evaporator. The crude product was washed with deionized water and then several times with diethyl ether. The structures of $4 \mathbf{a}-\mathbf{d}$ were confirmed by ${ }^{1} \mathrm{H} /{ }^{13} \mathrm{C}$ NMR spectra.

\subsubsection{General procedure for the synthesis of the naphthoquinone-thiazole hybrids bearing adamantane (6a-d)}

1-Adamantyl bromomethyl ketone $(1.5 \mathrm{mmol})$ solution in acetone $(20 \mathrm{~mL})$ was added drop by drop to a stirred solution of 1,4-naphthoquinone $N$-aroylthioureas $(1 \mathrm{mmol})$ in acetone $(30 \mathrm{~mL})$ and the formed reaction mixture was stirred for $24 \mathrm{~h}$ under reflux temperature. The solvent was evaporated under reduced pressure after the reaction was completed, and then ethyl acetate was used for extraction. Purification of the crude mixture was performed by column chromatography (ethyl acetate:hexane, 1:3)

N-(3-(3-Amino-1,4-dioxo-1,4-dihydronaphthalen-2-yl)-4-(p-tolyl)thiazol-2(3H)-ylidene)adamantane-1-carboxamide (6a)

Orange powder. Yield 0.39 g, $75 \%$; m.p.: $>300{ }^{\circ} \mathrm{C} ; \mathrm{Rf}=0.32$ (EtOAc:hexane / 1:3); IR $\left(\mathrm{cm}^{-1}\right): \mathrm{U}_{\max } 3329$, $3182,3071,2902,2850,1652,1614 .{ }^{1} \mathrm{H}$ NMR $(400 \mathrm{MHz}$, DMSO-d $): \delta=8.16(\mathrm{dd}, 1 \mathrm{H}, J=7.5 \mathrm{~Hz}, 0.8 \mathrm{~Hz}, \mathrm{Ar}-\mathrm{H})$, $7.99(\mathrm{dd}, 1 \mathrm{H}, J=7.5 \mathrm{~Hz}, 0.8 \mathrm{~Hz}$, Ar-H), 7.93-7.84 (m, 3H, N-H, Ar-H), 7.76-7.72 (m, 3H, N-H, Ar-H), 7.08 (d, $2 \mathrm{H}, J=8.0 \mathrm{~Hz}, \mathrm{Ar}-\mathrm{H}), 6.68\left(\mathrm{~s}, 1 \mathrm{H}, \mathrm{C}-\mathrm{H}\right.$ thiazole), $2.24\left(\mathrm{~s}, 3 \mathrm{H}, \mathrm{CH}_{3}\right), 1.89-1.79(\mathrm{~m}, 9 \mathrm{H}, \mathrm{C}-\mathrm{H}$ adamantane), $1.62-$ $1.51\left(\mathrm{~m}, 6 \mathrm{H}, \mathrm{C}-\mathrm{H}\right.$ adamantane). ${ }^{13} \mathrm{C}$ NMR (100 MHz, DMSO- $\left.d_{6}\right): \delta=181.3(\mathrm{C}=\mathrm{O}), 177.2(\mathrm{C}=\mathrm{O}), 172.7(\mathrm{C}=\mathrm{O})$, $170.6(\mathrm{C}=\mathrm{N}), 147.3,147.2,141.1,135.6,134.6,133.0,132.2,130.1,128.6(2 \times \mathrm{C}), 128.4(2 \times \mathrm{C}), 126.5,126.1,114.3$, 104.1, $40.2\left(3 \times \mathrm{CH}_{2}\right), 36.0\left(3 \times \mathrm{CH}_{2}\right), 35.6,27.7(3 \times \mathrm{CH}), 20.9\left(\mathrm{CH}_{3}\right)$. HRMS (ESI-TOF-MS): calcd. for $\mathrm{C}_{31} \mathrm{H}_{29} \mathrm{~N}_{3} \mathrm{O}_{5} \mathrm{~S}$ $[\mathrm{M}+\mathrm{Na}] 546.1827$; found 546.1828 .

N-(3-(3-Amino-1,4-dioxo-1,4-dihydronaphthalen-2-yl)-4-(4-(tert-butyl)phenyl)thiazol-2(3H)-ylidene)adamantane-1carboxamide $(\mathbf{6 b})$

Orange powder. Yield, 0.44 g, 78\%; m.p.: $>300^{\circ} \mathrm{C}$; Rf $=0.53$ (EtOAc:hexane / 1:3); IR $\left(\mathrm{cm}^{-1}\right): \mathrm{U}_{\max } 3443$, $3292,3148,2960,2907,2851,1651,1626 .{ }^{1} \mathrm{H}$ NMR $(400 \mathrm{MHz}$, DMSO-d 6 ): $\delta=8.17$ (dd, $1 \mathrm{H}, J=7.6 \mathrm{~Hz}, 1.2 \mathrm{~Hz}$, Ar-H), 8.00 (dd, 1H, J = 7.6 Hz, 1.2 Hz, Ar-H), $7.94(\mathrm{~s}, 1 \mathrm{H}, \mathrm{N}-\mathrm{H}), 7.92(\mathrm{td}, 1 \mathrm{H}, J=7.5 \mathrm{~Hz}, 1.4 \mathrm{~Hz}, \mathrm{Ar}-\mathrm{H}), 7.86$ (td, $1 \mathrm{H}, J=7.5 \mathrm{~Hz}, 1.4 \mathrm{~Hz}, \mathrm{Ar}-\mathrm{H}), 7.81-7.79(\mathrm{~m}, 2 \mathrm{H}, \mathrm{Ar}-\mathrm{H}), 7.75(\mathrm{~s}, 1 \mathrm{H}, \mathrm{N}-\mathrm{H}), 7.31-7.29(\mathrm{~m}, 2 \mathrm{H}, \mathrm{Ar}-\mathrm{H}), 6.69(\mathrm{~s}, 1 \mathrm{H}$, C-H thiazole), 1.89-1.79 (m, 9H, C-H adamantane), 1.62-1.51 (m, 6H, C-H adamantane), 1.21 (s 9H, C(CH3) $)_{3}$. ${ }^{13} \mathrm{C}$ NMR (100 MHz, DMSO- $\left.d_{6}\right): \delta=181.3(\mathrm{C}=\mathrm{O}), 177.1(\mathrm{C}=\mathrm{O}), 172.7(\mathrm{C}=\mathrm{O}), 170.7(\mathrm{C}=\mathrm{N}), 154.1,147.2(2 \times \mathrm{C})$, 135.7, 134.5, 133.0, 132.2, 130.1, $128.3(2 \times \mathrm{C}), 126.5,126.1,124.8(2 \times \mathrm{C}), 114.3,104.2,40.2\left(3 \times \mathrm{CH}_{2}\right), 36.0(3 \times$ $\left.\mathrm{CH}_{2}\right)$, 35.6, $34.6\left(\mathrm{C}, \mathrm{C}\left(\mathrm{CH}_{3}\right)_{3}\right), 30.9\left(3 \times \mathrm{C}, \mathrm{C}\left(\mathrm{CH}_{3}\right)_{3}\right), 27.7(3 \times \mathrm{CH})$. HRMS (ESI-TOF-MS): calcd. for $\mathrm{C}_{34} \mathrm{H}_{35} \mathrm{~N}_{3} \mathrm{O}_{3} \mathrm{~S}$ $[\mathrm{M}+\mathrm{H}]^{+}$566.2477; found 566.2468.

\section{N-(3-(3-Amino-1,4-dioxo-1,4-dihydronaphthalen-2-yl)-4-(4-chlorophenyl)thiazol-2(3H)-ylidene)adamantane-1-} carboxamide (6c)

Orange powder. Yield, $0.46 \mathrm{~g}, 85 \%$; m.p.: $>300{ }^{\circ} \mathrm{C}$; $\mathrm{Rf}=0.45$ (EtOAc:hexane / 1:3); IR $\left(\mathrm{cm}^{-1}\right): \mathrm{U}_{\max } 3436$, $3227,3149,2913,2852,1651,1622 \mathrm{~cm}^{-1}$; ${ }^{1} \mathrm{H}$ NMR $\left(400 \mathrm{MHz}, \mathrm{DMSO}-d_{6}\right): \delta=8.18$ (dd, $1 \mathrm{H}, J=7.5 \mathrm{~Hz}, 1.0 \mathrm{~Hz}, \mathrm{Ar}-$ $\mathrm{H}), 8.02(\mathrm{dd}, 1 \mathrm{H}, J=7.5 \mathrm{~Hz}, 1.0 \mathrm{~Hz}, \mathrm{Ar}-\mathrm{H}), 7.96(\mathrm{~s}, 1 \mathrm{H}, \mathrm{N}-\mathrm{H}), 7.94(\mathrm{td}, 1 \mathrm{H}, J=7.5 \mathrm{~Hz}, 1.4 \mathrm{~Hz}, \mathrm{Ar}-\mathrm{H}), 7.90-7.86$ $(\mathrm{m}, 3 \mathrm{H}, \mathrm{Ar}-\mathrm{H}), 7.80$ (s, 1H, N-H), 7.41-7.38 (m, 2H, Ar-H), 6.77 (s, 1H, C-H thiazole), 1.91-1.81 (m, 9H, C-H adamantane), 1.64-1.53 (m, 6H, C-H adamantane). ${ }^{13} \mathrm{C}$ NMR (100 MHz, DMSO- $\left.d_{6}\right): \delta=181.2(\mathrm{C}=\mathrm{O}), 177.1$ $(\mathrm{C}=\mathrm{O}), 171.7(\mathrm{C}=\mathrm{O}), 171.1(\mathrm{C}=\mathrm{N}), 147.7,147.2,136.1,136.0,135.7,133.0,132.1,130.1(3 \times \mathrm{C}), 128.2(2 \times \mathrm{C}), 126.5$, 126.1, 114.1, 104.7, $40.2\left(3 \times \mathrm{CH}_{2}\right), 35.9\left(3 \times \mathrm{CH}_{2}\right), 35.6,27.7(3 \times \mathrm{CH})$. HRMS (ESI-TOF-MS): calcd. for $\mathrm{C}_{30} \mathrm{H}_{26} \mathrm{ClN}_{3} \mathrm{O}_{3} \mathrm{~S}$ [M+Na] 566.1277; found 566.1281. 
N-(3-(3-Amino-1,4-dioxo-1,4-dihydronaphthalen-2-yl)-4-(2,4-dichlorophenyl)thiazol-2(3H)-ylidene)adamantane-1carboxamide (6d)

Orange powder. Yield, 0.47 g, 81\%; m.p.: 296-298 ${ }^{\circ} \mathrm{C}$ (decomp.); Rf = 0.41 (EtOAc:hexane / 1:3); IR (cm $\left.{ }^{1}\right): U_{\max } 3369,3180,2903,2846,1650,1610 .{ }^{1} \mathrm{H}$ NMR $\left(400 \mathrm{MHz}, \mathrm{DMSO}-d_{6}\right): \delta=8.10$ (dd, $1 \mathrm{H}, J=7.2 \mathrm{~Hz}, 0.9 \mathrm{~Hz}$, Ar-H), $7.98(\mathrm{dd}, 1 \mathrm{H}, J=7.2 \mathrm{~Hz}, 0.9 \mathrm{~Hz}, \mathrm{Ar}-\mathrm{H}), 7.93(\mathrm{~s}, 1 \mathrm{H}, \mathrm{N}-\mathrm{H}), 7.89(\mathrm{td}, 1 \mathrm{H}, J=7.5 \mathrm{~Hz}, 1.3 \mathrm{~Hz}, \mathrm{Ar}-\mathrm{H}), 7.82(\mathrm{td}$, $1 \mathrm{H}, J=7.5 \mathrm{~Hz}, 1.3 \mathrm{~Hz}, \mathrm{Ar}-\mathrm{H}), 7.75(\mathrm{~s}, 1 \mathrm{H}, \mathrm{N}-\mathrm{H}), 7.71(\mathrm{~d}, 1 \mathrm{H}, J=8.4 \mathrm{~Hz}, \mathrm{Ar}-\mathrm{H}), 7.47(\mathrm{~d}, 1 \mathrm{H}, J=2.0 \mathrm{~Hz}, \mathrm{Ar}-\mathrm{H})$, $7.34(\mathrm{dd}, 1 \mathrm{H}, J=8.4 \mathrm{~Hz}, 2.0 \mathrm{~Hz}, \mathrm{Ar}-\mathrm{H}), 6.79(\mathrm{~s}, 1 \mathrm{H}, \mathrm{C}-\mathrm{H}$ thiazole), 1.89-1.79 (m, 9H, C-H adamantane), 1.62$1.51\left(\mathrm{~m}, 6 \mathrm{H}, \mathrm{C}-\mathrm{H}\right.$ adamantane). ${ }^{13} \mathrm{C}$ NMR (100 MHz, DMSO- $\left.d_{6}\right): \delta=181.2(\mathrm{C}=\mathrm{O}), 177.0(\mathrm{C}=\mathrm{O}), 171.3(\mathrm{C}=\mathrm{O})$, $171.1(\mathrm{C}=\mathrm{N}), 147.7,147.3,135.6,135.4,135.0,133.0(2 \times \mathrm{C}), 132.7,132.2,130.1(2 \times \mathrm{C}), 126.9,126.4,126.1,114.0$, 105.0, $40.1\left(3 \times \mathrm{CH}_{2}\right), 35.9\left(3 \times \mathrm{CH}_{2}\right), 35.6,27.7(3 \times \mathrm{CH})$. HRMS (ESI-TOF-MS): calcd. for $\mathrm{C}_{30} \mathrm{H}_{25} \mathrm{Cl}_{2} \mathrm{~N}_{3} \mathrm{O}_{3} \mathrm{~S}[\mathrm{M}+\mathrm{H}]^{+}$ 578.1072; found 578.1064.

\subsection{Determination of antimicrobial activity}

Antimicrobial activities of $\mathbf{6 a}-\mathbf{d}$ were investigated by two-fold serial dilution method against sensitive organisms such as Pseudomonas aeruginosa (ATCC 9027), Legionella pneumophila subsp. pneumophila (ATCC 33152), and Escherichia coli (ATCC 10536) as Gram-negative bacteria; Enterococcus hirae (ATCC 10541), Bacillus cereus, and Staphylococcus aureus (ATCC 6538) as Gram-positive bacteria; and Candida albicans as a microfungus. Ampicillin and fluconazole were chosen as reference drugs. Model microorganisms $\left(10^{8}-10^{9} \mathrm{CFU} / \mathrm{mL}\right)$ were inoculated in medium containing the desired concentrations of $\mathbf{6 a - d}$ in 96-well microplates. After incubation at $37^{\circ} \mathrm{C}$ and stirring at $120 \mathrm{rpm}$ for 24 hours, microplates were read at $600 \mathrm{~nm}$.

\subsection{Determination of DNA cleavage activity}

The agarose gel electrophoresis method was utilized for the determination of DNA cleavage activity of compounds $6 \mathbf{a}-\mathbf{d}$. Test solution ( $5 \mu \mathrm{L} ; 250$ and $500 \mu \mathrm{g} / \mathrm{mL}$ ) was added to $5 \mu \mathrm{L}$ of pBR 322 plasmid DNA sample $(0.1 \mathrm{mg} / \mathrm{mL})$. The mixture was diluted with Tris buffer $(50 \mathrm{mM})$ and incubated for $1 \mathrm{~h}$ at $37^{\circ} \mathrm{C}$. Samples were then loaded on agarose gel containing ethidium bromide as the dye. Constant electricity $(80 \mathrm{~V})$ was applied for $90 \mathrm{~min}$. A UV transilluminator was used to monitor the bands.

\subsection{Determination of DPPH scavenging activity}

Antioxidant activity, based on the radical scavenging effect of the stable DPPH (2,2-diphenyl-1picrylhydrazyl) free radical, was studied for compounds $\mathbf{6 a - d}$, ascorbic acid, and Trolox. Stock solutions were prepared by dissolving $5 \mathrm{mg}$ of each compound in $5 \mathrm{~mL}$ of DMSO. Working solutions were prepared by dilution to desired concentrations, and then $0.5 \mathrm{~mL}$ of each solution of $\mathbf{6 a}-\mathbf{d}$ and $2 \mathrm{~mL}$ of DPPH radical solution were mixed and incubated for $30 \mathrm{~min}$ in the dark. The blank samples contained all reagents except the tested compounds. Absorbance values were measured at a wavelength of $517 \mathrm{~nm}$. The following equation was used for the calculation of free radical scavenging ability (eq. 1):

$$
\% \text { Inhibition Activity }=\left[\left(\mathrm{A}_{0}-\mathrm{A}_{1}\right) / \mathrm{A}_{0}\right] \times 100 \quad \text { Eq. } 1
$$

$\mathrm{A}_{0}$ : Control absorbance; $\mathrm{A}_{1}$ : the absorbance value of the solution containing compounds and DPPH after $30 \mathrm{~min}$.

\subsection{Determination of chelating activity}

The metal chelating activities of $\mathbf{6 a -} \mathbf{d}$ and EDTA were studied on the basis of the ferrozine method [49]. One millilitre of compound solutions at the desired concentration in DMSO, $0.1 \mathrm{~mL}$ of $\mathrm{FeCl}_{2} \cdot \mathrm{H}_{2} \mathrm{O}(2 \mathrm{mM})$, and $0.2 \mathrm{~mL}$ of ferrozine-1,2,4-triazine $(5 \mathrm{mM})$ were mixed in a test tube. The final volume was completed to $5 \mathrm{~mL}$ with ethanol. A blank reaction without compound was conducted under the same conditions. After incubation for $10 \mathrm{~min}$ at room temperature, activities were determined at $562 \mathrm{~nm}$. The chelating ability of the compounds for $\mathrm{Fe}^{2+}$ was calculated using the following equation 2:

$$
\text { Chelating Activity }(\%)=\left(\mathrm{A}_{\text {control }}-\mathrm{A}_{\text {sample }}\right) / \mathrm{A}_{\text {control }} \times 100 \quad \text { Eq. } 2
$$

Acontrol: Absorbance of the control reaction; Asample: the absorbance obtained in the presence of compounds or EDTA. 


\subsection{Determination of acidic dissociation constants}

Solutions of $\mathbf{6 a}-\mathbf{d}$ were prepared using DMSO at a concentration of $1.10^{-3} \mathrm{M}$. Stock solutions of $\mathrm{NaOH}$ $(0.025 \mathrm{M}), \mathrm{HCl}(0.1 \mathrm{M})$, and $\mathrm{NaCl}(1.0 \mathrm{M})$ were prepared in deionized water. $\mathrm{p} K_{\mathrm{a}}$ value determination was carried out based on our previously described method [22]. The Titroline 7000 automated titrator procedure [50] was used for calibrating the electrode system. A double-walled glass titration cell at $25.0 \pm 0.1^{\circ} \mathrm{C}$ equipped with a thermostat was used for potentiometric titrations. The titration cell was stirred at a constant rate using a magnetic stirrer during titration. $\mathrm{p} K_{\mathrm{a}}$ value determination was performed for compounds $6 \mathrm{a}-\mathbf{d}$ in $30 \%(\mathrm{v} / \mathrm{v}$ ) DMSO-water by addition of solutions of ligands $\mathbf{6 a}-\mathbf{d}(10 \mathrm{~mL}), \mathrm{HCl}(1 \mathrm{~mL})$, and $\mathrm{NaCl}(5 \mathrm{~mL})$ to the titration cell. DMSO (5 mL) and deionized water were added to the titration cell to finalize the volume of the solution to $50.00 \mathrm{~mL}$.

Acknowledgements: The Scientific and Technological Research Council of Turkey (TÜBİTAK, project grant 118Z407) is acknowledged for financial support.

Author contributions: Concept - A.D., S.O., M.S.Y., H.S., Y.N.; Design - A.D., S.O., M.S.Y., Y.N.; Supervision - Y.N.; Resources S.O., Y.N.; Materials -S.O., M.S.Y., Y.N..; Data Collection and/or Processing - A.D., S.O., M.S.Y., H.S., Y.N.; Analysis and/or Interpretation - A.D., S.O., M.S.Y., H.S., Y.N.; Literature Search - A.D., Y.N..; Writing - A.D., S.O., M.S.Y., H.S., Y.N.; Critical Reviews - A.D., S.O., M.S.Y., H.S., Y.N.

Conflict of interest statement: The authors declared no conflict of interest

\section{Appendix A. Supplementary Material}

Supplementary material related to this article can be accessed at https:/ /dx.doi.org/10.29228/jrp.20 .

\section{REFERENCES}

[1] Kuete V, Mbaveng AT, Sandjo LP, Zeino M, Efferth T. Cytotoxicity and mode of action of a naturally occurring naphthoquinone, 2-acetyl-7-methoxynaphtho [2, 3-b] furan-4, 9-quinone towards multifactorial drug-resistant cancer cells. Phytomedicine 2007; 33: 62-68. [CrossRef]

[2] Aminin D, Polonik S. 1, 4-Naphthoquinones: Some biological properties and application. Chem Pharm Bull. 2020; 68(1): 46-57. [CrossRef]

[3] Alferova VA, Shuvalov MV, Korshun VA, Tyurin AP. Naphthoquinone-derived polyol macrolides from natural sources. Russ Chem Bull. 2019; 68(5): 955-966. [CrossRef]

[4] Li K, Wang B, Zheng L, Yang K, Li Y, Hu M, He D. Target ROS to induce apoptosis and cell cycle arrest by 5, 7-dimethoxy-1, 4-naphthoquinone derivative. Bioorg Med Chem Lett. 2018; 28(3): $273-277$. [CrossRef]

[5] Gemili M, Nural Y, Keleş E, Aydıner B, Seferoğlu N, Ülger M, Şahin E, Erat S, Seferoğlu Z. Novel highly functionalized 1, 4-naphthoquinone 2-iminothiazole hybrids: Synthesis, photophysical properties, crystal structure, DFT studies, and anti(myco)bacterial/antifungal activity. J Mol Struct. 2019; 1196: 536-546. [CrossRef]

[6] Sánchez-Calvo JM, Barbero GR, Guerrero-Vásquez G, Durán AG, Macías M, Rodríguez-Iglesias MA, Molinillo JMG, Macías FA. Synthesis, antibacterial and antifungal activities of naphthoquinone derivatives: a structure-activity relationship study. Med Chem Res. 2016; 25(6): 1274-1285. [CrossRef]

[7] Nural Y, Ozdemir S, Doluca S, Demir B, Serkan Yalcin M, Atabey H, Kanat B, Erat S, Sari H, Seferoglu Z. Synthesis, biological properties, and acid dissociation constant of novel naphthoquinone-triazole hybrids. Bioorg Chem. 2020; 105: 104441. [CrossRef]

[8] Vale VV, Cruz JN, Viana GMR, Póvoa MM, Brasil DDSB, Dolabela MF. Naphthoquinones isolated from Eleutherine plicata herb: In vitro antimalarial activity and molecular modeling to investigate their binding modes. Med Chem Res. 2020; 29(3): 487-494. [CrossRef]

[9] Mathiyazhagan K, Kumaran A, Arjun P. Isolation of natural naphthoquinones from juglans regia and in vitro antioxidant and cytotoxic studies of naphthoquinones and the synthetic naphthofuran derivatives. Russ J Bioorg Chem. 2018; 44(3): 346-353. [CrossRef] 
[10] Abbas G, Hassan Z, Al-Harrasi A, Al-Adawi A, Ali M. Synthesis, biological evaluation, molecular docking and structure-activity relationship studies of halogenated quinone and naphthoquinone derivatives. J Mol Struct. 2019; 1195: 462-469. [CrossRef]

[11] Mohamady S, Gibriel AA, Ahmed MS, Hendy MS, Naguib BH. Design and novel synthetic approach supported with molecular docking and biological evidence for naphthoquinonehydrazinotriazolothiadiazine analogs as potential anticancer inhibiting topoisomerase-IIB. Bioorg Chem. 2020; 96: 103641. [CrossRef]

[12] Alimohammadi A, Mostafavi H, Mahdavi M. Thiourea Derivatives Based on the DapsoneNaphthoquinone Hybrid as Anticancer and Antimicrobial Agents: In Vitro Screening and Molecular Docking Studies. ChemistrySelect. 2020; 5(2): 847-852. [CrossRef]

[13] Manickam M, Boggu PR, Cho J, Nam YJ, Lee SJ, Jung SH. Investigation of chemical reactivity of 2-alkoxy1, 4-naphthoquinones and their anticancer activity. Bioorg Med Chem Lett. 2018; 28(11): 2023-2028. [CrossRef]

[14] Ullah S, Akter J, Kim SJ, Yang J, Park Y, Chun P, Moon HR. The tyrosinase-inhibitory effects of 2-phenyl1, 4-naphthoquinone analogs: importance of the (E)- $\beta$-phenyl-a, $\beta$-unsaturated carbonyl scaffold of an endomethylene type. Med Chem Res. 2019; 28(1): 95-103. [CrossRef]

[15] González A, Becerra N, Kashif M, González M, Cerecetto H, Aguilera E, Nogueda-Torres B, ChacónVargas KF, Zarate-Ramos JJ, Castillo-Velázquez U, Salas CO, Gildardo Rivera G, Vázquez K. In vitro and in silico evaluations of new aryloxy-1, 4-naphthoquinones as anti-Trypanosoma cruzi agents. Med Chem Res. 2020; 29: 665-674. [CrossRef]

[16] Wu Q, Er-bu, A, Liang X, Luan S, Wang Y, Yin Z, He C, Yin L, Zou Y, Li L, Song, X. Evaluation of antioxidant and anticancer activities of naphthoquinones-enriched ethanol extracts from the roots of Onosma hookeri Clarke. var. longiforum Duthie. Food Sci Nutr. 2020; 8(8): 4320-4329. [CrossRef]

[17] Sharma PC, Bansal KK, Sharma A, Sharma D, Deep A. Thiazole-containing compounds as therapeutic targets for cancer therapy. Eur J Med Chem. 2020; 188: 112016. [CrossRef]

[18] Arshadi S, Vessally E, Edjlali L, Hosseinzadeh-Khanmiri R, Ghorbani-Kalhor E. N-Propargylamines: versatile building blocks in the construction of thiazole cores. Beilstein J Org Chem. 2017; 13(1): 625-638. [CrossRef]

[19] Arora P, Narang R, Nayak SK, Singh SK, Judge V. 2, 4-Disubstituted thiazoles as multitargated bioactive molecules. Med Chem Res. 2016; 25(9): 1717-1743. [CrossRef]

[20] Ayati A, Emami S, Asadipour A, Shafiee A, Foroumadi A. Recent applications of 1, 3-thiazole core structure in the identification of new lead compounds and drug discovery. Eur J Med Chem. 2015; 97: 699-718. [CrossRef]

[21] Pawar CD, Sarkate AP, Karnik KS, Bahekar SS, Pansare DN, Shelke RN, Jawale CS, Shinde DB. Synthesis and antimicrobial evaluation of novel ethyl 2-(2-(4-substituted) acetamido)-4-subtituted-thiazole-5carboxylate derivatives. Bioorg Med Chem Lett. (2016); 26(15): 3525-3528. [CrossRef]

[22] Nural Y, Gemili M, Ulger M, Sari H, De Coen LM, Sahin E. Synthesis, antimicrobial activity and acid dissociation constants of methyl 5, 5-diphenyl-1-(thiazol-2-yl) pyrrolidine-2-carboxylate derivatives. Bioorg Med Chem Lett. 2018; 28(5): 942-946. [CrossRef]

[23] Nural Y, Gemili M, Yabalak E, De Coen LM, Ulger M. Green synthesis of highly functionalized octahydropyrrolo [3, 4-c] pyrrole derivatives using subcritical water, and their anti (myco) bacterial and antifungal activity. Arkivoc. 2018; 5: 51-64. [CrossRef]

[24] Nural, Y. Synthesis, antimycobacterial activity, and acid dissociation constants of polyfunctionalized 3[2-(pyrrolidin-1-yl) thiazole-5-carbonyl]-2H-chromen-2-one derivatives. Monatsh Chem. 2018; 149(10): 1905-1918. [CrossRef] 
[25] Madni M, Hameed S, Ahmed MN, Tahir MN, Al-Masoudi NA, Pannecouque C. Synthesis, crystal structure, anti-HIV, and antiproliferative activity of new pyrazolylthiazole derivatives. Med Chem Res. 2017; 26(10): 2653-2665. [CrossRef]

[26] Suma VR, Sreenivasulu R, Rao MVB, Subramanyam M, Ahsan MJ, Alluri R, Rao KRM. Design, synthesis, and biological evaluation of chalcone-linked thiazole-imidazopyridine derivatives as anticancer agents. Med Chem Res. 2020: 29(9); 1643-1654. [CrossRef]

[27] Zhang J, Xi J, He R, Zhuang R, Kong L, Fu L, Zhao Y, Zhang C, Zeng L, Lu J, Tao R, Liu Z, Zhu H, Liu S. Discovery of 3-(thiophen/thiazole-2-ylthio) pyridine derivatives as multitarget anticancer agents. Med Chem Res. 2019; 28(10): 1633-1647. [CrossRef]

[28] Abu-Melha S, Edrees MM, Salem HH, Kheder NA, Gomha SM, Abdelaziz MR. Synthesis and Biological Evaluation of Some Novel Thiazole-Based Heterocycles as Potential Anticancer and Antimicrobial Agents. Molecules (2019); 24(3): 539. [CrossRef]

[29] Nikalje APG, Tiwari SV, Sarkate AP, Karnik KS. Imidazole-thiazole coupled derivatives as novel lanosterol 14-a demethylase inhibitors: Ionic liquid mediated synthesis, biological evaluation and molecular docking study. Med Chem Res. 2018; 27(2): 592-606. [CrossRef]

[30] Kaur G, Singh JV, Gupta MK, Bhagat K, Gulati HK, Singh A, Bedi PMS, Singh H, Sharma, S. Thiazole-5carboxylic acid derivatives as potent xanthine oxidase inhibitors: design, synthesis, in vitro evaluation, and molecular modeling studies. Med Chem Res. 2020; 29(1): 83-93. [CrossRef]

[31] Wanka L, Iqbal K, Schreiner PR. The lipophilic bullet hits the targets: medicinal chemistry of adamantane derivatives. Chem Rev. 2013; 113(5): 3516-3604. [CrossRef]

[32] Štimac A, Šekutor M, Mlinarić-Majerski K, Frkanec L, Frkanec R. Adamantane in drug delivery systems and surface recognition. Molecules 2017; 22(2): 297. [CrossRef]

[33] Meloun M, Pilařová L, Pfeiferová A, Pekárek T. Method of UV-Metric and pH-Metric Determination of Dissociation Constants of Ionizable Drugs: Valsartan. J Solution Chem. 2019; 48(8-9): 1266-1286. [CrossRef]

[34] Gemili M, Sari H, Ulger M, Sahin E, Nural Y. Pt (II) and Ni (II) complexes of octahydropyrrolo [3, 4-c] pyrrole N-benzoylthiourea derivatives: Synthesis, characterization, physical parameters and biological activity. Inorg Chim Acta 2017; 463: 88-96. [CrossRef]

[35] Gorgun K, Sakarya HC, Ozkutuk M. The synthesis, characterization, acid dissociation, and theoretical calculation of several novel benzothiazole schiff base derivatives. J Chem Eng Data 2015; 60(3): 594-601. [CrossRef]

[36] Babić S, Horvat AJ, Pavlović DM, Kaštelan-Macan M. Determination of pKa values of active pharmaceutical ingredients. TrAC Trends Anal Chem. 2017; 26(11): 1043-1061. [CrossRef]

[37] Manallack DT. The pKa distribution of drugs: application to drug discovery. Perspect Med Chem. 2017; 1: 25-38. [CrossRef]

[38] El-Sherif AA, Shehata MR, Shoukry MM, Mahmoud N. Potentiometric Study of Speciation and Thermodynamics of Complex Formation Equilibria of Diorganotin (IV) Dichloride with 1-(2-Aminoethyl) piperazine. (2016) J Solution Chem. 2016; 45(3): 410-430. [CrossRef]

[39] Ozkutuk M, Ogretir C, Arslan T, Kandemirli F, Kokssoy B. Acid dissociation constants of some novel isatin thiosemicarbazone derivatives. J Chem Eng Data 2010; 55(8): 2714-2718. [CrossRef]

[40] Gemili M, Nural Y, Keleş E, Aydıner B, Seferoğlu N, Şahin E, Sarı E, Seferoğlu Z. Novel 1, 4naphthoquinone $\mathrm{N}$-aroylthioureas: Syntheses, crystal structure, anion recognition properties, DFT studies and determination of acid dissociation constants. J Mol Liq. 2018; 269: 920-932. [CrossRef]

[41] Grochowski DM, Uysal S, Aktumsek A, Granica S, Zengin G, Ceylan R, Locatelli M, Tomczyk M. In vitro enzyme inhibitory properties, antioxidant activities, and phytochemical profile of Potentilla thuringiaca. Phytochem Lett. 2017; 20: 365-372. [CrossRef] 
[42] Nural Y, Gemili M, Seferoglu N, Sahin E, Ulger M, Sari H. Synthesis, crystal structure, DFT studies, acid dissociation constant, and antimicrobial activity of methyl 2-(4-chlorophenyl)-7a-((4-chlorophenyl) carbamothioyl)-1-oxo-5,5-diphenyl-3-thioxo-hexahydro-1H-pyrrolo[1, 2-e]imidazole-6-carboxylate. J Mol Struct. 2018; 1160: 375-382. [CrossRef]

[43] El-Sherif AA, Shoukry MM, Abd-Elgawad MM. Protonation equilibria of some selected a-amino acids in DMSO-water mixture and their $\mathrm{Cu}$ (II)-complexes. J Solution Chem. 2013; 42(2): 412-427. [CrossRef]

[44] Altun Y, Köseoğlu F, Demirelli H, Yılmaz İ, Çukurovalı A, Kavak N. Potentiometric studies on nickel (II), copper (II) and zinc (II) metal complexes with new schiff bases containing cyclobutane and thiazole groups in 60\% dioxane-water mixture. J Braz Chem Soc. 2009; 20(2): 299-308. [CrossRef]

[45] Jia CY, Li JY, Hao GF, Yang GF. A drug-likeness toolbox facilitates ADMET study in drug discovery. Drug Discovery Today 2020; 25(1): 248-258. [CrossRef]

[46] Tian S, Wang J, Li Y, Li D, Xu L, Hou T. The application of in silico drug-likeness predictions in pharmaceutical research. Adv Drug Delivery Rev. 2015; 86: 2-10. [CrossRef]

[47] L.L.C. MolSoft. MolSoft Molecules in Silico (2020) http://molsoft.com/mprop/, Accessed 26th August 2020.

[48] Desai NC, Kotadiya GM, Trivedi AR. Studies on molecular properties prediction, antitubercular and antimicrobial activities of novel quinoline based pyrimidine motifs. Bioorg Med Chem Lett. 2014; 24(14): 3126-3130. [CrossRef]

[49] Dinis TCP, Madeira VMC, Almeida LM. Action of phenolic derivatives (acetaminophen, salicylate, and 5-aminosalicylate) as inhibitors of membrane lipid peroxidation and as peroxyl radical scavengers. Arch Biochem Biophy. 1994; 315(1): 161-169. [CrossRef]

[50] Pettit LD. (1992) Academic Software, Sourby Farm, Timble, Otley, LS21 2PW, UK. 